\title{
Productive and structural responses of Urochloa brizantha cv. piatã subjected to management strategies
}

\section{Respostas produtivas e estruturais do Urochloa brizantha cv. piatã submetido a estratégias de manejo}

\author{
Josimar Nogueira dos Santos ${ }^{1}$; Alexandre Lima de Souza ${ }^{2 *}$; Marcus Vinicius \\ Pavoni de Carvalho ${ }^{1}$; Mariane Moreno Ferro ${ }^{3}$; Anderson de Moura Zanine ${ }^{4}$
}

\begin{abstract}
This experiment was carried out to evaluate management strategies for Piatã grass grown in the soilclimatic conditions of the south region of Mato Grosso State, Brazil. The treatments corresponded to four management strategies determined by the following pre- and post-harvest heights: 30/10, 30/15, $35 / 20$ and 40/15. A completely randomized design with five replications was employed totaling twenty experimental units. The highest number of harvests was observed in the plots subjected to strategies $35 / 20$ and 30/15, which allowed for two additional harvest cycles when compared with strategies 40/15 and 30/10. The strategies that provided plants with the greatest pre-harvest heights, 40/15 and 35/20, resulted in lower leaf elongation rates, stem elongation rates, and leaf senescence. Because of the lower post-harvest height, strategy 30/10 resulted in the largest tiller population, an average of 829 tillers $\mathrm{m}^{2}$. The highest herbage accumulation value, $18.600 \mathrm{~kg} \mathrm{ha}^{-1} \mathrm{DM}$, was observed with management strategies $40 / 15$ and 30/15. The management of Piatã grass based on the harvest target of 30/15 associates elevated herbage production with a favorable pasture structure for grazing.
\end{abstract}

Key words: Defoliation intensity. Grazing management. Herbage accumulation.

\section{Resumo}

\begin{abstract}
Este experimento foi conduzido com o objetivo de avaliar as estratégias de manejo do capim Piatã cultivado nas condições solo-clima da região sul do Estado do Mato Grosso. Os tratamentos corresponderam a quatro estratégias de manejo determinadas pelas seguintes alturas pré e pós-colheita: 30/10, 30/15, $35 / 20$ e 40/15. Utilizou-se um delineamento inteiramente casualizado com cinco repetições, totalizando vinte unidades experimentais. $\mathrm{O}$ maior número de colheitas foi observado nas parcelas submetidas às estratégias $35 / 20$ e $30 / 15$, o que permitiu dois ciclos adicionais de colheita quando comparados com as estratégias $40 / 15$ e $30 / 10$. As estratégias que proporcionaram às plantas as maiores alturas pré-colheita, $40 / 15$ e $35 / 20$, resultaram em menores taxas de alongamento foliar, taxas de alongamento do colmo e senescência foliar. Devido à menor altura pós-colheita, a estratégia 30/10 resultou na maior população de perfilhos, uma média de 829 perfilhos $\mathrm{m}^{2}$. O maior valor de acúmulo de forragem, $18.600 \mathrm{~kg} \mathrm{ha}^{-1} \mathrm{de}$ MS, foi observado com as estratégias de manejo 40/15 e 30/15. O manejo do capim Piatã baseado na
\end{abstract}

\footnotetext{
1 Mestres em Ciência Animal, Universidade Federal de Mato Grosso, UFMT, Cuiabá, MT, Brasil. E-mail: josimarzoo@yahoo. com.br; pavoni.marcus@gmail.com

2 Prof., Universidade Federal de Mato Grosso, UFMT, Rondonópolis, MT, Brasil. E-mail: alexandre@ufmt.br

3 Dra em Ciência Animal, Universidade Federal de Mato Grosso, UFMT, Cuiabá, MT, Brasil. E-mail: mmf_zootecnia@yahoo. com.br

4 Prof., Universidade Federal do Maranhão, UFMA, Chapadinha, MA, Brasil. E-mail: anderson.zanine@ibest.com.br

* Author for correspondence
} 
meta de colheita de 30/15 associa a produção elevada de forragem a uma estrutura de pasto favorável ao pastejo.

Palavras-chave: Acúmulo de forragem. Intensidade de desfolha. Manejo do pastejo.

\section{Introduction}

The intensification of animal production on pasture can be achieved through the adoption of management techniques that allow an efficient defoliation while maintaining rapid and vigorous regrowth. In this perspective, a large part of restrictions to animal production can be solved with management practices that increase the efficiency in the use or harvest of the forage produced (BARBOSA et al., 2007).

Information about the herbage accumulation dynamics obtained by monitoring of the morphogenetic and structural characteristics has shown to be a tool to understand the morphophysiological responses of tropical grasses when they are subjected to defoliation actions from harvesting or grazing. This understanding can contribute to the better planning and adoption of efficient management practices suitable for each type of forage plant (RODRIGUES et al., 2011). In this way, it is possible to establish management strategies that allow a greater production and greater efficiency in pasture use.

The responses of a plant to the environment and to the management strategies results the main structural characteristics of the pasture: final leaf size, tiller density, number of live leaves per tiller, and leaf:stem ratio. The importance of these traits is because the leaf area index (LAI), considered a structural variable, has a higher correlation with the responses of both plants and animals and results from the combined manifestation of morphogenetic and structural characteristics of plants in a given environment (CHAPMAN; LEMAIRE, 1993).

Cultivars are constantly released in Brazil to be used in pasture-based systems. Despite the economic importance of marandu grass, problems such as the death syndrome of marandu grass associated with the need to intensify production systems, in a sustainable way, have led to a search for new grass varieties that more competitive in quantity and qualify, especially less demanding in soil fertility, with lower seasonality of production and more resistant to pests and diseases (VALLE et al., 2009).

Although of Piatã grass has been released in 2006 as results of the work of the program of improvement of tropical forages of the Embrapa Gado de Corte few papers have been published about the productive responses of tropical grasses under different management conditions. Due of the large territory and great variations in soil-climatic conditions in the country, there is limited scientific information about the productive responses of tropical grasses under different management conditions. For the main tropical grasses, it is possible to determine pasture-management strategies based on targets characterized by combinations between intensity and frequency of defoliation (GIACOMINI et al., 2009; TRINDADE et al., 2007; ZANINE et al., 2011), which enable the maintenance of the pasture structure in ideal conditions for an adequate animal performance.

Thus, the objective of the present study was to evaluate the morphogenetic and structural characteristics and herbage accumulation of Urochloa brizantha cv. Piatã subjected to different harvest regimes under the climatic conditions of the South Region of Mato Grosso State.

\section{Material and Methods}

The experiment was carried out in an experimental area at Rondonópolis Campus of the Federal University of Mato Grosso (16 $28^{\circ}$

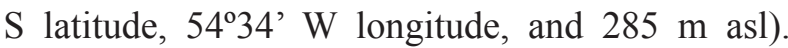


According to Köppen classification, the climate of the region is an Aw type, characterized by irregular distribution of rainfall over the year, with welldefined dry and rainy periods.
The experimental period was of 186 days. Information about the climatic conditions during the experimental period (Figure 1) was obtained from a weather station located $400 \mathrm{~m}$ from the experimental area.

Figure 1. Monthly accumulated precipitation and minimum, average, and maximum temperatures (T) (monthly means) observed during the experimental period.

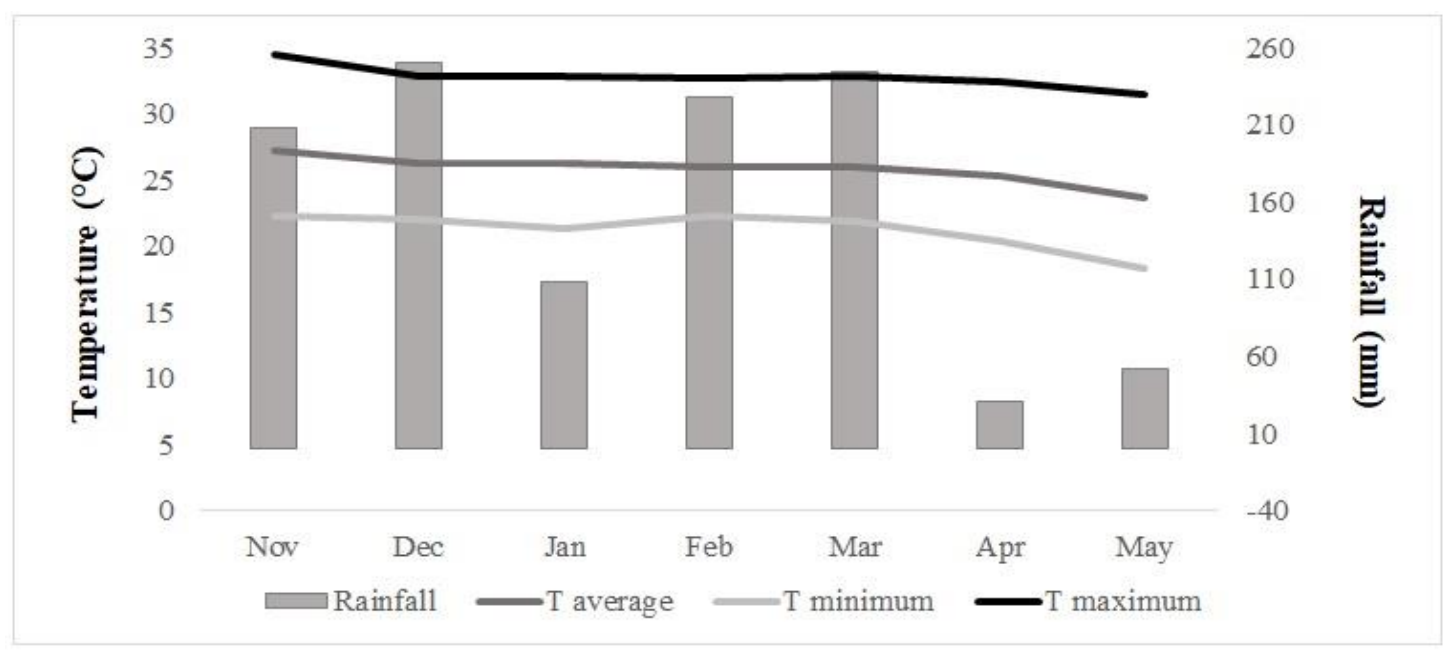

Average soil chemical characteristics: $\mathrm{pH}$ in $\mathrm{CaCl}_{2}=4.9 ; \mathrm{P}=1.7 \mathrm{mg} / \mathrm{dm}^{3} ; \mathrm{K}=29 \mathrm{mg} / \mathrm{dm}^{3} ; \mathrm{Ca}^{2+}=1$ $\mathrm{cmol}_{\mathrm{c}} / \mathrm{dm}^{3} ; \mathrm{Mg}^{2+}=1 \mathrm{cmol} / \mathrm{dm}^{3} ; \mathrm{H}+\mathrm{Al}^{3+}=2.9 \mathrm{cmol}_{\mathrm{c}} /$ $\mathrm{dm}^{3} ; \mathrm{Al}^{3+}=0.1 \mathrm{cmol}_{\mathrm{c}} / \mathrm{dm}^{3} ;$ organic matter $=13.5 \mathrm{~g} /$ $\mathrm{kg}$; sum of bases $=2.1 \mathrm{cmol} / \mathrm{dm}^{3}$; cation-exchange capacity $=4.5 \mathrm{cmol}_{\mathrm{c}} / \mathrm{dm}^{3}$; base saturation $=46 \%$; clay $=400 \mathrm{~g} / \mathrm{kg} ;$ silt $=100 \mathrm{~g} / \mathrm{kg}$; and total sand $=500$ $\mathrm{g} / \mathrm{kg}$. To maintain the soil fertility, $50 \mathrm{~kg} \mathrm{ha}^{-1} \mathrm{P}_{2} \mathrm{O}_{5}$ were applied in the form of single superphosphate, $150 \mathrm{~kg} \mathrm{ha}^{-1}$ nitrogen (N) in the form of urea, and $75 \mathrm{~kg} \mathrm{ha}^{-1} \mathrm{~K}_{2} \mathrm{O}$ in the form of potassium chloride $\left(\mathrm{K}_{2} \mathrm{O}\right)$, following recommendations of Cantarutti et al. (1999). The phosphate fertilizer was applied in a single dose, whereas the nitrogen and potassium fertilizers were split into three applications.

The planting of the Piatã grass being was done in plots of $4.0 \times 3.0 \mathrm{~m}$, with the sowing done in lines with spacing of $32 \mathrm{~cm}$. A completely randomized design with four treatments and five replications was adopted. Treatments corresponded to four management strategies determined by the following pre- and post-harvest heights: 30/10 (30 and $10 \mathrm{~cm}$, respectively); 30/15 (30 and $15 \mathrm{~cm}$, respectively); $35 / 20$ (35 and $20 \mathrm{~cm}$, respectively); and 40/15 (40 and $15 \mathrm{~cm}$, respectively).

The experiment started after cutting plants in the plots, according each treatment $(10,15$, and $20 \mathrm{~cm})$. The grass height was monitored twice weekly, by sampling 10 random points per plot. Heights were read at the midpoint of the curvature of the upper leaves located around the ruler.

Morphogenetic characteristics were evaluated during the plant regrowth period and immediately after the harvest. Ten tillers were used per experimental unit; these were tagged with colored ribbons for identification and to facilitate their visualization. The morphological components of the tillers were measured twice weekly using a millimeter-graduated ruler. The length of the pseudostem (stem plus leaf sheath) was measured 
from the soil to the ligule of the last fully expanded leaf. The length of fully expanded leaves was obtained by measuring the distance from the ligule to the live tip of the leaf blade, while the length of expanding leaves was measured from the ligule of the last live leaf to the tip of the leaf under expansion. Leaves were classified as expanded when their ligule was visible and considered dead when more than $50 \%$ of the leaf blade showed senescence.

Based on the above information, the following variables were calculated: leaf appearance rate (LAR), leaf elongation rate (LER), pseudostem elongation rate, phyllochron, leaf lifespan (LLS), average leaf length, leaf senescence rate, and number of live leaves per tiller (NLL), following Marcelino et al. (2006). Tiller density was estimated by counting the number of existing tillers within the sward. For this procedure, a $0.15 \times 1.0 \mathrm{~m}$ metal frame was placed in two representative points of the plot.

The net herbage accumulation, based on tissue flow, was determined in accordance with Grant et al. (1983), according to which, at the end of each regrowth interval, 10 tillers were collected at random per experimental unit and taken to the laboratory for separation and measurement ( $\mathrm{mm}$ ) of green leaves and stems. Next, these fractions were dried in a forced-air oven at $60^{\circ} \mathrm{C}$ for $72 \mathrm{~h}$. Based on the length and weight values, it was estimated the weight indices per unit of green leaf and stem lengths. With these data plus the leaf elongation rate, stem elongation rate, leaf senescence rate, and tiller density values, they were estimated the herbage accumulation and leaf:stem ratio.

The data were subjected to analysis of variance and Tukey's test for comparison of means at the 5\% significance level, using SAEG (System for Statistical Analysis, version 9.1).

\section{Results and Discussion}

The management strategies influenced $(\mathrm{P}<0.05)$ the total number of harvests performed during the experimental period. The highest number of harvests occurred in the plots subjected to strategies $30 / 15$ and $35 / 20$, which allowed for two additional cycles as compared with strategies $30 / 10$ and $40 / 15$ (Figure 2). This was a response to the effect of the regrowth interval, which was significantly affected $(\mathrm{P}<0.05)$ by the management targets, because during the experimental period, the shortest regrowth interval was observed for strategy $35 / 20$, followed by strategy $30 / 15$ (Table 1).

Figure 2. Number of harvests and interval between harvests of Piatã grass subjected to management strategies.

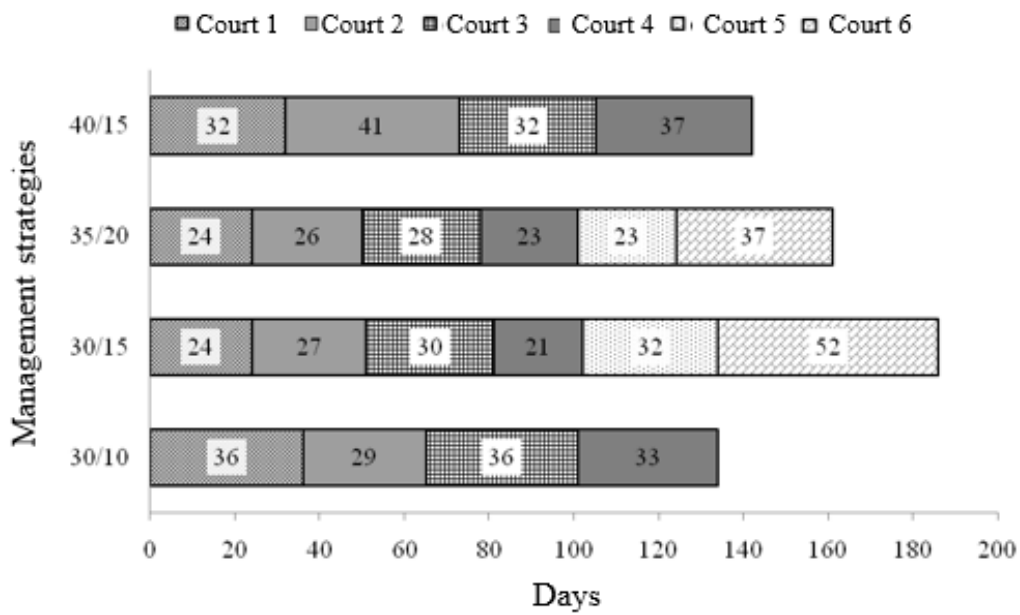


Table 1. Mean values for the intervals between harvests and for morphogenetic and structural traits of Piatã grass subjected to different harvest intensities and frequencies.

\begin{tabular}{lcccc}
\hline \multirow{2}{*}{\multicolumn{1}{c}{ Variable }} & \multicolumn{3}{c}{ Management strategy } \\
\cline { 2 - 5 } & $30 / 10$ & $30 / 15$ & $35 / 20$ & $40 / 15$ \\
\hline Average interval between harvests (days) & $33.5 \mathrm{~B}$ & $31.0 \mathrm{C}$ & $26.8 \mathrm{D}$ & $35.5 \mathrm{~A}$ \\
Leaf appearance rate $\left(\right.$ leaf tiller ${ }^{-1}$ day $\left.^{-1}\right)$ & $0.109 \mathrm{~A}$ & $0.101 \mathrm{~B}$ & $0.115 \mathrm{~A}$ & $0.107 \mathrm{~A}$ \\
Leaf elongation rate $\left(\mathrm{mm} \mathrm{tiller}^{-1} \mathrm{day}^{-1}\right)$ & $26.31 \mathrm{~B}$ & $26.46 \mathrm{~B}$ & $30.46 \mathrm{~A}$ & $31.47 \mathrm{~A}$ \\
Stem elongation rate $\left(\mathrm{mm} \mathrm{tiller}^{-1}\right.$ day $\left.^{-1}\right)$ & $2.18 \mathrm{~B}$ & $2.07 \mathrm{~B}$ & $2.85 \mathrm{~A}$ & $3.51 \mathrm{~A}$ \\
Leaf lifespan (days) & $52.3 \mathrm{~B}$ & $58.7 \mathrm{~A}$ & $50.6 \mathrm{~B}$ & $52 \mathrm{~B}$ \\
Leaf senescence rate $\left(\mathrm{mm}\right.$ tiller $^{-1}$ day $\left.^{-1}\right)$ & $2.77 \mathrm{~B}$ & $3.19 \mathrm{~B}$ & $3.06 \mathrm{~B}$ & $4.38 \mathrm{~A}$ \\
Number of live leaves & $5.4 \mathrm{~A}$ & $5.3 \mathrm{~A}$ & $5.4 \mathrm{~A}$ & $5.4 \mathrm{~A}$ \\
Average leaf length $(\mathrm{mm})$ & $154 \mathrm{~B}$ & $143 \mathrm{C}$ & $157 \mathrm{~B}$ & $184 \mathrm{~A}$ \\
Tiller density & $829 \mathrm{~A}$ & $782 \mathrm{~B}$ & $697 \mathrm{BC}$ & $683 \mathrm{C}$ \\
\hline
\end{tabular}

Means followed by common letters in the row do not differ statistically by Tukey's test $(\mathrm{P}>0.05)$.

The shorter regrowth intervals and consequent larger number of harvest cycles recorded in strategies $30 / 15$ and $35 / 20$ can be attributed to differences between the heights of the plants preand post-harvest. In the management strategy with the targets of $30 / 15$ and $35 / 20$, this difference was $15 \mathrm{~cm}$, whereas in strategies $30 / 10$ and $40 / 15$, this difference was 20 and $25 \mathrm{~cm}$, respectively. For this reason, strategies $30 / 15$ and $35 / 20$ required a shorter regrowth interval for plants to reach the established targets for the pre-harvest heights. In the $35 / 20$ strategy, the greater post-harvest height and consequently larger remaining-leaf area promoted a faster regrowth, with more frequent harvests.

The leaf appearance rate (LAR) was influenced $(\mathrm{P}<0.05)$ by the harvesting strategies tested (Table 1$)$, with an average of 0.110 leaves tiller ${ }^{-1}$ day $^{-1}$ recorded for strategies $30 / 10,35 / 20$, and 40/15, which did not differ from each other, and 0.101 leaves tiller ${ }^{-1}$ day $^{-1}$ for strategy 30/15. The difference in LAR in experiments evaluating residual heights under grazing or harvesting has been associated on the heights of remaining leaf sheaths, i.e., the distance traveled by the leaf to emerge (MARTUSCELLO et al., 2006; SANTOS et al., 2011).

A longer sheath causes the plant to show a lower LAR. In the present study, the observed responses did not follow this pattern. This result agrees with
Marcelino et al. (2006), who also did not observe an effect of the harvesting intensities of 10 and $20 \mathrm{~cm}$ on the leaf appearance rate of Marandu palisadegrass. In a study of Piatã grass under growth, Silveira et al. (2010) reported an average leaf appearance rate of 0.09 leaves tiller ${ }^{-1}$ day $^{-1}$, which is lower than that found here. By contrast, Marcelino et al. (2006) found an increase in leaf appearance rate for more frequent harvests in Marandu palisadegrass pastures subjected to the defoliation frequencies based on the appearance of 5, 7, or 9 leaves per tiller and defoliation intensities of 10 and $20 \mathrm{~cm}$ residual height. Contrary, Costa Junior et al. (2019) did not find differences between different height management strategies of piatã grass.

For leaf elongation rate (LER), a significant effect $(\mathrm{P}<0.05)$ of the target heights was also observed. The strategies based on plants with a greater pre-harvest height (35/20 and 40/15), resulted in higher values for this variable; the average was $30.96 \mathrm{~mm}^{\text {tiller }} \mathrm{r}^{-1}$ day $^{-1}$ (Table 1), which was very close to the 30.3 $\mathrm{mm}$ tiller $^{-1}$ day $^{-1}$ observed by Silveira et al. (2010) for Piatã grass. Casagrande et al. (2010) did not find alterations in leaf elongation rate evaluated marandu grass, recording an average of $17.5 \mathrm{~mm} \mathrm{tiller}^{-1}$ day $^{-1}$. The variation in leaf elongation rate between these grasses may be due to the morphological differences inherent to each cultivar. 
According to Davies (1974), the defoliation intensity has little influence on the leaf elongation rate, with a slight decrease observed in this variable only when defoliation occurs or when the tiller is fully cut, which did not occur in the present study. Thus, the differences seem to be related to the greater pasture heights used in strategies 35/20 and 40/15. Pena et al. (2009) reported that this response pattern can be attributed to the increase in the apical meristem resulting from stem elongation, which shortens the distance traveled by the leaf until its emergence above the pseudostem.

The stem elongation rate changed with the harvest strategies $(\mathrm{P}<0.05)$, with mean values of 2.8 and $3.5 \mathrm{~mm} \mathrm{tiller}^{-1}$ day $^{-1}$ for strategies $35 / 20$ and 40/15, respectively, which did not differ from each other. These values were, on average, $60 \%$ higher than those obtained with the other strategies (Table 1). In Xaraés grass fertilized with a nitrogen dose equivalent to $150 \mathrm{~kg} \mathrm{ha}^{-1}$, Cabral et al. (2012) observed a stem elongation rate of $5.16 \mathrm{~mm}^{\text {tiller }}{ }^{-1}$ day $^{-1}$ in the rainy season.

The higher stem elongation rates observed for strategies $35 / 20$ and $40 / 15$ are explained by the competition for light resulting from the shading of the lower leaves, caused by the greater sward height. This response pattern was observed in some experiments using light interception as indicative of the harvest frequency or plant grazing (SOUSA et al., 2011; TRINDADE et al., 2007).

Based on these results, it is possible that in strategies 35/20 and 40/15 the Piatã grass reached a light interception level greater than $95 \%$, indicating that these strategies might have led to a higher percentage accumulation of stem. It should be noted that in addition to reducing the forage quality because of the lower nutritional value, the stem fraction also compromises the pasture structure, which may considerably interfere with the aspects involved in the process of use of the herbage by the grazing animal.
Leaf lifespan was affected $(\mathrm{P}<0.05)$ by the management strategy (Table 1), with mean values that ranged from 50.6 to 58.7 days and the highest value observed in strategy 30/15. Leaf lifespan is the product between number of live leaves and phyllochron. Thus, because there was no difference in number of live leaves, the longer leaf lifespan in strategy $30 / 15$ is attributed to the longer phyllochron observed in this strategy.

The greater competition for light determined by the elongation rate and leaf length in strategies $35 / 20$ and 40/15 can also explain the shorter leaf lifespan in the management strategy adopting these targets. Martuscello et al. (2006) observed a reduction of leaf lifespan that is explained by the greater tissue renewal brought about by the nitrogen fertilization doses. The authors also explained that, in unfertilized plants, leaves have a longer lifespan over the expansion of new leaves, in a process that was evidenced from LER and the higher LAR and consequent reduction of phyllochron in fertilized plants.

An effect of the management strategies was observed on the leaf senescence rate of the Piatã grass $(\mathrm{P}<0.05)$. The average $4.38 \mathrm{~mm}^{\text {tiller }}{ }^{-1}$ day ${ }^{1}$ obtained with strategy 40/15 for leaf senescence rate was $46 \%$ higher than the average of the other strategies, which did not differ from each other (Table 1). The observed difference can be attributed to the longer regrowth period in the plots managed under strategy 40/15. With the shading of the lower sward strata, caused by the prolonged regrowth period, the competition for light among the plants intensifies the senescence process, which is also explained by the shorter lifespan of the leaves for this strategy.

It should be stressed that the losses stemming from the higher leaf senescence rates generated in strategy 40/15 can represent inefficiency in the process of forage use. Therefore, there may be a reduction in the carrying capacity of the pastures 
caused by the lower number of accumulated live leaves, which consequently affects the nutritive value of the herbage produced and the animal performance.

There was no effect $(\mathrm{P}>0.05)$ of the harvest strategies on number of live leaves, which was 5.4 per tiller (Table 1). This value is very close to the 5.8 leaves tiller ${ }^{-1}$ reported by Silveira et al. (2010) for the same grass under free growth and the 3.6 to 4.5 leaves tiller ${ }^{-1}$ found by Casagrande et al. (2010) for Marandu palisadegrass subjected to different herbage allowances.

Based on these results, a maximum regrowth period equivalent to the number of days necessary for the appearance of 5 to 6 leaves tiller-1 can be recommended for the Piatã grass, which will ensure lower losses due to senescence and greater efficiency in the use of the herbage produced. Although the grazing management using number of live leaves is an appropriate parameter for application in the field, this variable does not reflect the structural condition of the pasture or the quality of the herbage provided to the animals, which requires other criteria to be evaluated so that the best management can be established.

Unlike number of live leaves, average leaf length varied $(\mathrm{P}<0.05)$ according to the management targets adopted. In strategy 40/15, the leaves were on average $22 \%$ longer as compared with those observed in strategy $30 / 15$, which showed the lowest value for this variable (Table 1). This response ratifies Briske (1996), who stated that the final leaf length is a plastic trait sensitive to the defoliation management.

The literature seems to have a consensus regarding the factors determining leaf size. Several researchers (DURU; DUCROCQ, 2000; WILSON; LAIDLAW, 1985) have shown that the leaf length is directly related to the length of the pseudostem, which determines the distance to be travelled from the leaf until it is fully expanded. In this way, the greater leaf length found in strategy $40 / 15$ can be explained by the higher stem elongation rates and length, which are a result of the greater pasture height observed in this strategy.

The tiller density was influenced $(\mathrm{P}>0.05)$ by the harvesting strategies. Mean values ranged from 683 to 829 tillers $\mathrm{m}^{2}$, and the highest value was observed in strategy 30/10 (Table 1). This tiller density is close to the 1,069 to 692 tillers $\mathrm{m}^{2}$ reported by Sbrissia and Silva (2008) in Marandu palisadegrass under continuous rate managed between 10 and 40 $\mathrm{cm}$ in height, respectively.

In the plots managed using strategy 30/10, the lower plant height pre-harvest in relation to strategies 35/20 and 40/15 and the lower residual in relation to the other strategies may have benefited the quantity and quality of the incident light into the pasture. Variations in the quantity and quality of light that penetrates the sward are among the main factors determining morpho-physiological alterations in plants, which result in an increased or reduced tiller population (SBRISSIA; SILVA, 2008). Additionally, in pastures managed under frequent defoliations, plants utilize a larger tiller population as a strategy to optimize their leaf area index (KORTE, 1986).

The management strategies affected $(\mathrm{P}<0.05)$ the total herbage accumulation; the highest values for this variable were recorded with targets 30/15 and 40/15, which did not differ from each other even with a distinct number of harvests, resulting in approximately $18,000 \mathrm{~kg} \mathrm{ha}^{-1} \mathrm{DM}$ (Table 2). However, each component of the accumulated herbage should be carefully analyzed for a precise evaluation of what can be used by the animal. 
Table 2. Net herbage accumulation and leaf:stem ratio of Piatã grass subjected to management strategies.

\begin{tabular}{ccc}
\hline Management strategy & Net herbage accumulation & Leaf:stem ratio \\
\hline $30 / 10$ & $14.781 \mathrm{~B}$ & $3.28 \mathrm{~A}$ \\
$30 / 15$ & $17.318 \mathrm{~A}$ & $3.32 \mathrm{~A}$ \\
$35 / 20$ & $14.168 \mathrm{~B}$ & $2.95 \mathrm{~A}$ \\
$40 / 15$ & $18.648 \mathrm{~A}$ & $2.20 \mathrm{~B}$ \\
\hline
\end{tabular}

Means followed by the same letter in the column do not differ statistically by Tukey's test $(\mathrm{P}>0.05)$.

It is noteworthy that the lower number of harvests observed in strategy $40 / 15$ in relation to $30 / 15$ was compensated for by the greater herbage accumulation per harvest, which can be explained by the lower harvest frequency observed with this strategy (Figure 2). An analogous response pattern was reported by Pedreira et al. (2007) for Xaraés grass. This was not observed in strategy $35 / 20$, which resulted in two additional harvests relative to combination 40/15; however, it resulted in an approximately $31 \%$ lower herbage accumulation. Additionally, the higher leaf and stem elongation rates contributed to the high herbage accumulation found in strategy 40/15.

The leaf:stem ratio was influenced $(\mathrm{P}<0.05)$ by the management strategies. The values observed for the plots subjected to strategies $30 / 10,30 / 15$, and $35 / 20$ were like each other, and higher than those obtained with strategy 40/15 (Table 2). The leaf:stem ratio is one of the factors determining ease at seizure (FLORES et al., 2008), and the nutritional value of the herbage consumed by animals (PENA et al., 2009), suggesting that the treatments with highest values for this variable can be beneficial for animal performance.

\section{Conclusion}

To achieve high efficiency levels in production and use of Piatã grass, the pre-harvest or grazing height of $30 \mathrm{~cm}$ should be adopted as the target strategy in conjunction with a post-harvest or grazing height of $15 \mathrm{~cm}$. This strategy allows for an elevated herbage accumulation, associated with a favorable leaf:stem ratio for grazing animals. Strategy 40/15 can be employed in production systems with low manageability. The longer regrowth intervals observed with this strategy can provide flexibility to management strategies at the farm.

\section{References}

BARBOSA, R. A.; NASCIMENTO JUNIOR, D.; EUCLIDES, V. P. B.; DA SILVA, S. C.; ZIMMER, A. H.; TORRES JUNIOR, R. A. A. Capim tanzânia submetido a combinações entre intensidades e frequência de pastejo. Pesquisa Agropecuária Brasileira, Brasília, v. 42 , n. 3 , p. $329-340,2007$. DOI: $10.1590 /$ S0100204X2007000300005

BRISKE, D. D. Strategies of plant survival in grazed systems: a functional interpretation. In: HODGSON, J; ILLIUS, A. W. (Ed.). The ecology and management of grazing systems. London: CAB International, 1996. p. 37-67.

CABRAL, W. B.; SOUZA, A. L. S.; ALEXANDRINO, E.; TORAL, F. L. B.; SANTOS, J. N.; CARVALHO, M. V. P. Características estruturais e agronômicas da Brachiaria brizantha cv. Xaraés submetida a doses de nitrogênio. Revista Brasileira de Zootecnia, Viçosa, v. 41 , n. 4 , p. $846-855,2012$. DOI: $10.1590 / \mathrm{S} 1516-$ 35982012000400004

CANTARUTTI, R. B.; MARTINS, C. E.; CARVALHO, M. M.; FONSECA, D. M.; ARRUDA, M. E.; VILELA, H.; OLIVEIRA, R. T. T. Pastagens. In: RIBEIRO, A. C.; GUIMARÃES, P. T. G.; ALVAREZ V. V. H. (Ed.). Recomendações para o uso de corretivos e fertilizantes em Minas Gerais: 5a aproximação. Viçosa: CFSEMG/ UFV, 1999. $212 \mathrm{p}$.

CASAGRANDE, D. R.; RUGGIERI, A. C.; JANUSCKIEWICZ, E. R.; GOMIDE, J. A.; REIS, R. A.; VALENTE, A. L. S. Características morfogênicas e estruturais do capim-marandu manejado sob pastejo intermitente com diferentes ofertas de forragem. Revista 
Brasileira de Zootecnia, Viçosa, v. 39, n. 10, p. 21082115, 2010. DOI: 10.1590/S1516-35982010001000002

CHAPMAN, D. F.; LEMAIRE, G. Morphogenetic and structural determinats of plant regrowth after defoliation. In: BAKER, M. J. (Ed.). Grassands for our world. Wellington: Sir Publishing, 1993. 95-104 p.

COSTA JUNIOR, W. D.; ALEXANDRINO, E.; PAULA NETO, J. J.; REZENDE, J. M. Effect of post-grazing residual leaf blade-length on the regrowth vigor of Piatã grass grazed under intermittent stocking. Semina: Ciências Agrárias, Londrina, v. 40, n. 1, p. 271-282, 2019. DOI: $10.5433 / 1679-0359.2019 v 40 \mathrm{n} 1 \mathrm{p} 271$

DAVIES, A. Leaf tissue remaining after cutting and regrowth in perennial ryegrass. Journal of Agriculture Science, Toronto, v. 82, n. 1, p. 165-172, 1974. DOI: $10.1017 / \mathrm{S} 0021859600050334$

DURU, M.; DUCROCQ, H. Growth and senescence of the successive grass leaves on a tiller. Ontogenic development and effect of temperature. Annals of Botany, Oxford, v. 85 , n. 5, p. 635-643, 2000. DOI: $10.1006 /$ anbo. 2000.1116

FLORES, R. S.; EUCLIDES, V. P. B.; ABRÃO, M. P. C.; GALBEIRO, S.; DIFANTE, G. S.; BARBOSA, R. A. Desempenho animal, produção de forragem e características estruturais dos capins marandu e xaraés submetidos a intensidades de pastejo. Revista Brasileira de Zootecnia, Viçosa, v. 37, n. 8, p. 1355-1365, 2008. DOI: $10.1590 / \mathrm{S} 1516-35982008000800004$

GIACOMINI, A. A.; SILVA, S. C.; SARMENTO, D. O. L.; ZEFERINO, C. V.; SOUZA JUNIOR, S. J.; TRINDADE, J. K.; GUARDA, V. D. A.; NASCIMENTO JUNIOR, D. Growth of marandu palisade grasss wards subjected to strategies of intermittent stocking. Scientia Agricola, Piracicaba, v. 66, n. 6, p. 733-741, 2009. DOI: 10.1590/S0103-90162009000600003

GRANT, S. A.; BARTHRAM, G. T.; TORVELL, L.; KING, J.; SMITH, H. K. Sward management, lamina turnover and tiller population density in continuously stocked Lolium perenne-dominated swards. Grass and Forage Science, Oxford, v. 38, n. 4, p. 333-344, 1983. DOI: $10.1111 /$ j.1365-2494.1983.tb01657.x

KORTE, C. J. Tillering in "Grassland Nui" perennial ryegrass swards. 2 . Seasonal patterno of tillering and age of flowering tillers with two mowing frequencies. New Zealand Journal of Agricultural Research, Lincoln, v. 29, p. 629-638, 1986.

MARCELINO, K. R. A.; NASCIMENTO JUNIOR, D.; DA SILVA, S. C.; EUCLIDES, V. P. B.; FONSECA, D. M. Características morfogênicas e estruturais e produção de forragem do capim-marandu submetido a intensidades e frequências de desfolhação. Revista Brasileira de Zootecnia, Viçosa, v. 35, n. 6, p. 2243-2252, 2006. DOI: 10.1590/S1516-35982006000800007

MARTUSCELLO, J. A.; FONSECA, D. M.; NASCIMENTO JUNIOR, D.; SANTOS, P. M.; CUNHA, D. N. F.; MOREIRA, L. M. Características morfogênicas e estruturais de capim-massai submetido a adubação nitrogenada e desfolhação. Revista Brasileira de Zootecnia, Viçosa, v. 35, n. 3, p. 665-671, 2006. DOI: 10.1590/S1516-35982006000300006

PEDREIRA, B. C.; PEDREIRA, C. G. S.; DA SILVA, S. C. Estrutura do dossel e acúmulo de forragem de Brachiaria brizantha cultivar Xaraés em resposta a estratégias de pastejo. Pesquisa Agropecuária Brasileira, Brasília, v. 42, n. 2, p. 281-287, 2007. DOI: 10.1590/ S0100-204X2007000200018

PENA, K. S.; NASCIMENTO JUNIOR, D.; SILVA, S. C.; EUCLIDES, V. P. B.; ZANINE, A. M. Características morfogênicas, estruturais e acúmulo de forragem do capim-tanzânia submetido a duas alturas e três intervalos de corte. Revista Brasileira de Zootecnia, Viçosa, v. 38 , n. 11 , p. $2127-2136,2009$. DOI: 10.1590/S151635982009001100009

RODRIGUES, C. S.; NASCIMENTO JUNIOR, D.; SILVA, S. C.; SILVEIRA, M. C. T.; SOUSA, B. M. L.; DETMANN, E. Characterization of tropical forage grass development pattern through the morphogenetic and structural characteristics. Revista Brasileira de Zootecnia, Viçosa, v. 40, n. 3, p. 527-534, 2011. DOI: 10.1590/S1516-35982011000300009

SANTOS, M. E. R.; FONSECA, D. M.; BRAZ, T. G. S.; SILVA, S. P.; GOMES, V. M.; SILVA, G. P. Características morfogênicas e estruturais de perfilhos de capim Brachiaria em locais do pasto com alturas variáveis. Revista Brasileira de Zootecnia, Viçosa, v. 40 , n. 3, p. $535-542$, 2011. DOI: $10.1590 / \mathrm{S} 1516-$ 35982011000300010

SBRISSIA, A. F.; SILVA, S. C. Compensação tamanho/ densidade populacional de perfilhos em pastos de capim-marandu. Revista Brasileira de Zootecnia, Viçosa, v. 37, n. 1, p. 35-47, 2008. DOI: 10.1590/S151635982008000100005

SILVEIRA, M. C. T.; NASCIMENTO JUNIOR, D.; SILVA, S. C.; EUCLIDES, V. P. B.; MONTAGNER, D. B.; SBRISSIA, A. F.; RODRIGUES, C. S.; SOUZA, B. M. L.; PENA, K. S.; VILELA, H. H. Morphogenetic and structural comparative characterization of tropical forage grass cultivar sunder free growth. Scientia Agricola, Piracicaba, v. 67, n. 2, p. 136-142, 2010. DOI: 10.1590/ S0103-90162010000200002 
SOUSA, B. M. L.; NASCIMENTO JR., D.; DA SILVA, S. C.; MONTEIRO, H. C. F.; RODRIGUES, C. S.; FONSECA, D. M.; SBRISSIA, A. F. Morphogenetic and structural characteristics of xaraes palisadegrass submitted to cutting heights. Revista Brasileira de Zootecnia, Viçosa, v. 40, n. 1, p. 53-59, 2011. DOI: 10.1590/S1516-35982011000100008

TRINDADE, J. K.; SILVA, S. C.; SOUZA JÚNIOR, S. J.; GIACOMINI, A. A.; ZEFERINO, C. V.; GUARDA, V. D. A.; CARVALHO, P. C. F. Composição morfológica da forragem consumida por bovinos de corte durante o rebaixamento do capim-marandu submetido a estratégias de pastejo rotativo. Pesquisa Agropecuária Brasileira, Brasília, v. 42, n. 6, p. 883-890, 2007. DOI: 10.1590/ S0100-204X2007000600016

UNIVERSIDADE FEDERAL DE VICOSA - UFV. SAEG - Sistema para análises estatísticas. versão 9.1: Fundação Arthur Bernardes, UFV: Viçosa, 2007.
VALLE, C. B.; RESENDE, R. M. S. O melhoramento de forrageiras tropicais no Brasil. Revista Ceres, Viçosa, v. 56, n. 4, p. 460-472, 2009.

ZANINE,A.M.; NASCIMENTO JUNIOR, D.; SANTOS, R. M. S.; PENA, C. K.; SILVA, S. C.; SBRISSIA, A. F. Características estruturais e acúmulo de forragem em capim-tanzânia sob pastejo rotativo. Revista Brasileira de Zootecnia, Viçosa, v. 40, n. 11, p. 2015-2022, 2011. DOI: $10.1590 /$ S1516-35982011001100012

WILSON, R. E.; LAIDLAW, A. S. The role of the sheath tube in the development of expanding leaves in perennial ryegrass. Annals of Applied Biology, Newport, v. 106, n. 2, p. 385-391, 1985. DOI: 10.1111/j.1744-7348.1985. tb03128.x 